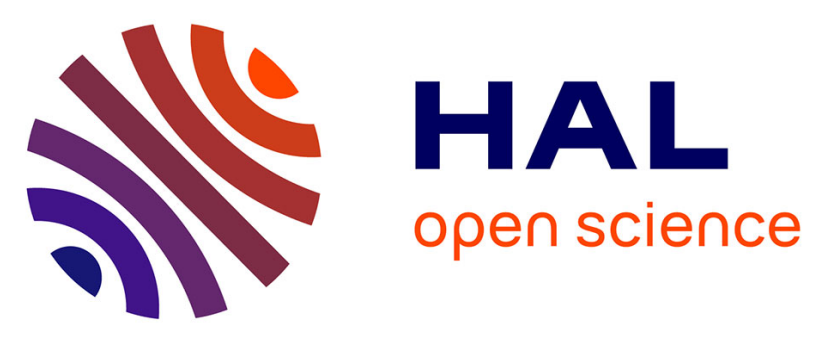

\title{
An Exploratory Investigation of Spinel LiMn 1.5 Ni 0.5 O 4 as Cathode Material for Potassium-Ion Battery
}

Ankush Bhatia, Jean Pierre Pereira-Ramos, Nicolas Emery, Barbara Laïk, Ronald Smith, Rita Baddour-Hadjean

\section{To cite this version:}

Ankush Bhatia, Jean Pierre Pereira-Ramos, Nicolas Emery, Barbara Laïk, Ronald Smith, et al.. An Exploratory Investigation of Spinel LiMn 1.5 Ni 0.5 O 4 as Cathode Material for Potassium-Ion Battery. ChemElectroChem, 2020, 7 (16), pp.3385-3385. 10.1002/celc.202000889 . hal-02988376

\section{HAL Id: hal-02988376 https://hal.science/hal-02988376}

Submitted on 6 Nov 2020

HAL is a multi-disciplinary open access archive for the deposit and dissemination of scientific research documents, whether they are published or not. The documents may come from teaching and research institutions in France or abroad, or from public or private research centers.
L'archive ouverte pluridisciplinaire HAL, est destinée au dépôt et à la diffusion de documents scientifiques de niveau recherche, publiés ou non, émanant des établissements d'enseignement et de recherche français ou étrangers, des laboratoires publics ou privés. 


\title{
An Exploratory Investigation of Spinel $\mathrm{LiMn}_{1.5} \mathrm{Ni}_{0.5} \mathrm{O}_{4}$ as Cathode
}

\section{Material for Potassium-Ion Battery}

\author{
Mr. A. Bhatia ${ }^{[b]}$, Dr. J.-P. Pereira-Ramos ${ }^{[b]}$, Dr. N. Emery ${ }^{[b]}$, Dr. B. Laïk ${ }^{[b]}$, Dr R. I. Smith ${ }^{[c]}$, Dr. R. \\ Baddour-Hadjean*[a] \\ [a] Institut de Chimie et des Matériaux Paris Est (ICMPE) \\ UMR 7182 CNRS-Université Paris Est Créteil \\ 2 rue Henri Dunant, 94320 Thiais, France \\ E-mail: baddour@icmpe.cnrs.fr \\ [b] Institut de Chimie et des Matériaux Paris Est (ICMPE) \\ UMR 7182 CNRS-Université Paris Est Créteil \\ 2 rue Henri Dunant, 94320 Thiais, France \\ [c] ISIS Facility, STFC Rutherford Appleton Laboratory, \\ Harwell Oxford, Didcot, Oxfordshire OX11 OQX, United Kingdom \\ Supporting information for this article is given via a link at the end of the document
}

\begin{abstract}
The emerging interest in $\mathrm{K}$-ion batteries (KIBs) increases the importance of cathodes with high working voltage in this system. The $\mathrm{LiMn}_{1.5} \mathrm{Ni}_{0.5} \mathrm{O}_{4}$ spinel is a promising alternative for the next generation of high voltage Li-ion positive electrodes and its delithiated structure could be of interest for KIBs. In this work, Li ions are extracted from $\mathrm{LiMn}_{1.5} \mathrm{Ni}_{0.5} \mathrm{O}_{4}$ by a first electrochemical oxidation. The electroformed $\lambda-\mathrm{Mn}_{0.75} \mathrm{Ni}_{0.25} \mathrm{O}_{2}$ spinel phase is shown to convert into layered $\mathrm{K}_{0.5} \mathrm{Mn}_{0.75} \mathrm{Ni}_{0.25} \mathrm{O}_{2}(\mathrm{KMNO})$ at $20^{\circ} \mathrm{C}$ along the first discharge in $\mathrm{K}$ cell. Then, $0.3 \mathrm{~K}^{+} / \mathrm{KNMO}\left(90 \mathrm{mAh} \mathrm{g}^{-1}\right)$ are reversibly exchanged during the subsequent cycle. Superior electrochemical performance are reported for $\mathrm{KMNO}$ as compared to $\mathrm{K}_{0.5} \mathrm{MnO}_{2}(\mathrm{KMO})$ : a higher working voltage vs. $\mathrm{K}^{+} / \mathrm{K}(3.10 \mathrm{~V}$ vs. $2.79 \mathrm{~V})$, enhanced rate capability and better cycling stability $\left(70 \mathrm{mAh} \mathrm{g}^{-1}\right.$ after 60 cycles at $\mathrm{C} / 20$ for KMNO vs. $40 \mathrm{mAh} \mathrm{g}^{-1}$ for $\mathrm{KMO}$ ). The contribution of the Ni redox system is revealed as a reason for these improved performances.
\end{abstract}

\section{Introduction}

On the recent research front for the next generation secondary batteries beyond Li [1-5], potassium insertion into graphite in nonaqueous cells has brought new insights into the electrochemical $\mathrm{K}^{+}$intercalation behavior and introduced advantageous benefits from potassium [6-9]. Since potassium resources are much abundant and the standard potential of $\mathrm{K}^{+} / \mathrm{K}$ is only $0.13 \mathrm{~V}$ above that of $\mathrm{Li}^{+} / \mathrm{Li}\left(-2.92 \mathrm{~V}\right.$ vs. SHE compared to $-3.05 \mathrm{~V}$ for $\left.\mathrm{Li}^{+} / \mathrm{Li}\right)$, potassium-ion batteries (KIBs) can be regarded as an appealing alternative to lithium-ion batteries (LIBs) to realize high voltage systems with low cost. The crucial issue that needs to be overcome is the development of cathode materials able to accommodate the large $\mathrm{K}^{+}$ion $\left(\mathrm{Li}^{+}<\mathrm{Na}^{+}<\mathrm{K}^{+}, 0.76<1.02<1.38\right.$ $\AA$ in terms of ionic radius) without displaying significant structural changes detrimental to cycle life and rate capability performance. Up until now, very few promising KIB cathode materials have been successfully reported. Three main categories of compounds have been explored: polyanionic compounds such as $\mathrm{KVPO}_{4} \mathrm{~F}$ [10] and $\mathrm{K}_{3} \mathrm{~V}_{2}\left(\mathrm{PO}_{4}\right)_{3}$ [11], hexacyanometalates such as Prussian blue $\mathrm{KFe}_{2}(\mathrm{CN})_{6}$ [12], Prussian blue analogs [13] and layered oxides such as $\mathrm{K}_{0.3} \mathrm{MnO}_{2}$ [14, 15], $\mathrm{K}_{0.45} \mathrm{MnO}_{2}$ [15], $\mathrm{K}_{0.5} \mathrm{MnO}_{2}$ [16], $\mathrm{K}_{0.7} \mathrm{Fe}_{0.5} \mathrm{Mn}_{0.5} \mathrm{O}_{2}$ nanowires [17], $\mathrm{K}_{0.45} \mathrm{Mg}_{0.1} \mathrm{Mn}_{0.9} \mathrm{O}_{2} \quad$ [18],
$\mathrm{K}_{0.5} \mathrm{Ni}_{0.1} \mathrm{Mn}_{0.9} \mathrm{O}_{2}$ [19], $\mathrm{K}_{0.67} \mathrm{Mn}_{0.83} \mathrm{Ni}_{0.17} \mathrm{O}_{2}$ [20], $\mathrm{K}_{0.54} \mathrm{Co}_{0.5} \mathrm{Mn}_{0.5} \mathrm{O}_{2}$ [21], $\mathrm{K}_{\mathrm{x}} \mathrm{CoO}_{2}[22,23], \mathrm{K}_{0.5} \mathrm{~V}_{2} \mathrm{O}_{5}$ [24] or $\mathrm{Na}_{0.9} \mathrm{Cr}_{0.9} \mathrm{Ru}_{0.1} \mathrm{O}_{2}$ [25] . Specific capacities between 90-120 mAh g$^{-1}$ have been reported for Mn-based layered oxides, depending on the structure, the chemical composition and the voltage range [14- 21]. An outstanding discharge capacity of $178 \mathrm{mAh} \mathrm{g}^{-1}$ is achieved for $\mathrm{K}_{0.7} \mathrm{Fe}_{0.5} \mathrm{Mn}_{0.5} \mathrm{O}_{2}$ nanowires, due to the contribution of the two redox systems $\mathrm{Fe}^{4+} / \mathrm{Fe}^{3+}$ and $\mathrm{Mn}^{4+} / \mathrm{Mn}^{3+}$, even when the nature of the mechanism is not discussed [17].

Besides these cathode materials, a compound of interest is the $3 \mathrm{D}$ phase $\lambda-\mathrm{MnO}_{2}(\lambda-\mathrm{MO})$ with the spinel structure, first isolated by Hunter et al. [26]. While previous studies have investigated the sodium insertion properties into chemically [27] or electrochemically prepared $\lambda$-MO [28], potassium insertion in such spinel framework has not been reported yet. On the other hand, recent works on LIBs have focused considerable attention on the high voltage nickel-manganese spinels operating near $5 \mathrm{~V}$ vs. $\mathrm{Li}^{+} / \mathrm{Li}$ [29-32]. Of the various chemistries that have been explored, the $4.7 \mathrm{~V}$ vs. $\mathrm{Li}^{+} / \mathrm{Li} \mathrm{LiMn}_{1.5} \mathrm{Ni}_{0.5} \mathrm{O}_{4}$ material (LMNO) provides substantial improvements over the unmodified $\mathrm{LiMn}_{2} \mathrm{O}_{4}$ (LMO) structure, due to a $0.7 \mathrm{~V}$ increase in the oxidation/reduction potential with considerably high reversibility associated with the $\mathrm{Ni}^{2+} \leftrightarrows \mathrm{Ni}^{3+} \leftrightarrows \mathrm{Ni}^{4+}$ redox reactions. It comes out that another candidate of great interest for potassium insertion, and never investigated yet, is the vacant $\lambda-\mathrm{Mn}_{0.75} \mathrm{Ni}_{0.25} \mathrm{O}_{2}(\lambda-\mathrm{MNO})$ structure operating at a higher voltage than the $\lambda$-MO spinel.

In this paper, we investigate the properties of electrochemically prepared $\lambda-\mathrm{MO}$ and $\lambda$-MNO spinel structures in potassium-metal cells. We show that both materials are capable of reacting with potassium ions along the first discharge in $\mathrm{KPF}_{6} / \mathrm{EC}: \mathrm{PC}$ electrolyte to convert to layered phases, namely $\mathrm{K}_{0.42} \mathrm{MnO}_{2}(\mathrm{KMO})$ and $\mathrm{K}_{0.5} \mathrm{Mn}_{0.75} \mathrm{Ni}_{0.25} \mathrm{O}_{2}$ (KMNO), respectively. A comparative analysis of the electrochemical properties (cycling and rate capability) between $\mathrm{KMO}$ and $\mathrm{KMNO}$ highlights the even greater performance of the Ni-substituted KMNO electrode as cathode material for KIBs. 


\section{Results and Discussion}

\section{Characterization of as-prepared LMO, LMNO powders and electrochemically synthesized $\lambda$-MO, $\lambda$-MNO electrodes}

SEM images of the as-prepared LMO and LMNO powders (Fig. 1) show well crystallized particles $<2 \mu \mathrm{m}$ in size with a perfect octahedral shape showing smooth surfaces. The XRD patterns of the as-prepared powders are shown in Fig. 2a. The Rietveldrefinement of XRD patterns are shown in Figs. S1a-c. The structural parameters are gathered in Tables S1 and S2. As shown in Fig. 2a, all the diffraction peaks can be indexed in the $F d-3 m$ space group in agreement with the JCPDS database (card $\mathrm{N}^{\circ}$ 80-2162) of cubic spinel. The Rietveld-refinements of XRD patterns lead to cubic lattice parameters of $a=8.246 \AA$ and $a=$ $8.179 \AA$, respectively, in good agreement with those previously reported for LMO [33] and LMNO [34, 35]. The spinel structures of LMO and LMNO are illustrated in Figs. S1b-d. The presence of weak intensity reflections at ca. $2 \theta=43.8^{\circ}$ and $51.3^{\circ}$ in the XRD pattern of LMNO (see enlarged view in Fig. S2) are attributed to traces of the rock salt phase (S.G. Fm-3m) which is formed due to oxygen loss at annealing temperatures higher than $\sim 700^{\circ} \mathrm{C}$. The exact chemical composition of rock-salt impurities has not been determined yet but it has been suggested to be $\mathrm{Li}_{1-x} \mathrm{Ni}_{x} \mathrm{O}$, $\left(\mathrm{Li}_{x} \mathrm{Mn}_{0.66} \mathrm{Ni}_{0.34}\right)_{y} \mathrm{O}$ and/or $\mathrm{Ni}_{6} \mathrm{MnO}_{8}$ [36]. The Rietveld refinement of PND data (Fig.2b) confirms the disordered $\mathrm{Fd}-3 \mathrm{~m}$ structure of the LMNO powder.
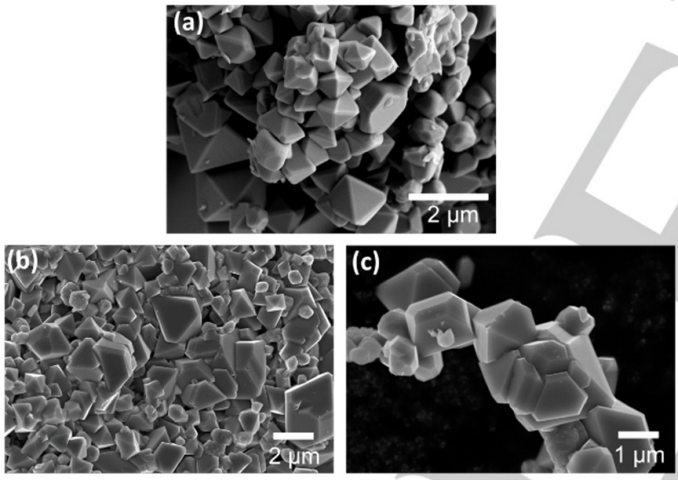

Figure 1. SEM images of (a) LMO; (b, c) LMNO as-prepared powders.

The Raman spectra of the as-prepared powders are shown in Fig. 2c. The typical fingerprint of LMO is composed of broad features that can be deconvoluted into five components corresponding to the symmetry species expected in the $F d-3 m$ space group $\left(F_{2 g}(1)\right.$, $E_{g}, F_{2 g}(2), A_{1 g}$ and $\left.F_{2 g}(3)\right)$, located at $195,350,434,574$ and 611 $\mathrm{cm}^{-1}$ (Table 1) [37-39]. The $611 \mathrm{~cm}^{-1}$ peak is assigned to the symmetric $\mathrm{Mn}-\mathrm{O}$ stretching vibrations of the $\mathrm{MnO}_{6}$ octahedrons [40]. Introduction of $\mathrm{Ni}$ in the spinel structure of LMO induces an intensity increase of the overall spectrum as well as some splitting of bands due to the participation of $\mathrm{Ni}$ and $\mathrm{Mn}$ to metal-oxygen vibrations. Indeed, 8 main bands are observed for LMNO (Fig. 2c), located at $160,212,404,499,525,593,610$ and $635 \mathrm{~cm}^{-1}$ that can be assigned by analogy with the parent compound LMO (Table 1) [38]. It is worth noting that the rich Raman fingerprint characteristic of ordering of the $\mathrm{Ni}(\mathrm{II})$ and $\mathrm{Mn}(\mathrm{IV})$ in space group $P 4332$, showing additional peaks at $221,240,251,293,325,378$ and $462 \mathrm{~cm}^{-1}$ is not detected, which confirms the disordered nature of our LMNO sample $[40,41]$.

Table 1. Experimental Raman wavenumbers (in $\mathrm{cm}^{-1}$ ) and their assignments for LMO, $\lambda$-MO, LMNO and $\lambda$-MNO. Cubic lattice parameters are also indicated.

\begin{tabular}{|lcccc|}
\hline & LMO & $\lambda$-MO & LMNO & $\lambda$-MNO \\
\hline $\begin{array}{l}\text { Lattice } \\
\text { parameter } \\
(\AA)\end{array}$ & 8.246 & 8.041 & 8.179 & 8.007 \\
$F_{2 g}(1)$ & 195 & ---- & $160 / 212$ & 172 \\
$E_{g}$ & 350 & 462 & 404 & 455 \\
$F_{2 g}(2)$ & 434 & 498 & $499 / 525$ & 495 \\
$\mathrm{~A}_{1 g}$ & 574 & 589 & $593 / 610 / 635$ & $542 / 597 / 635$ \\
$F_{2 g}(3)$ & 611 & 600 & --- & -- \\
\hline
\end{tabular}

Electrochemical delithiation curves of LMO and LMNO are shown in Fig. 3a. Charging LMO in a lithium cell involves a capacity of $137 \mathrm{mAh} \mathrm{g}-1$, indicating the extraction of $0.93 \mathrm{Li} / \mathrm{mole}$ of spinel oxide (black curve in Fig. 3a). The X-ray diffraction pattern of the fully charged material (Fig. 3b) can be indexed in the $\lambda$-MO cubic unit cell. The shrinkage occurring upon lithium extraction, from a $=8.25 \AA$ to $a=8.04 \AA$ (Table 1), is in good agreement with previous reports (8.24 to $8.03 \AA$ ) [26]. The Raman spectrum of the fully charged electrode (Fig. 3c) displays the characteristic features previously reported for $\lambda$-MO $[38,39,42,43]$. This spectrum is composed of 4 bands located at 462, 498, 589 and $600 \mathrm{~cm}^{-1}$ assigned respectively to the $E_{g}, F_{2 g}(2), A_{1 g}$ and $F_{2 g}(3)$ phonons (Table 1) $[38,39]$. The strong $A_{1 g}$ mode at $589 \mathrm{~cm}^{-1}$ corresponds to the $\mathrm{Mn}^{4+}-\mathrm{O}$ stretching vibration. The lowest wavenumber band of $F_{2 g}(1)$ symmetry at $195 \mathrm{~cm}^{-1}$ could not be experimentally observed (Table 1 ).

Charging LMNO in a lithium cell leads to a capacity of $140 \mathrm{mAh}$ $\mathrm{g}^{-1}$ corresponding to the composition $\mathrm{Li}_{0.04} \mathrm{Ni}_{0.5} \mathrm{Mn}_{1.5} \mathrm{O}_{4}$ (red curve in Fig. 3a). This clearly indicates a quasi-quantitative delithiation of LMNO. The XRD pattern of the fully charged electrode (Fig. $3 \mathbf{b})$, termed as $\lambda$-MNO, can be indexed in the same $F d-3 m$ space group than LMNO, in agreement with the JCPDS database (card $N^{\circ} 80-2162$ ). However, a shift in the diffraction lines toward higher $2 \theta$ angles indicates a contraction of the cubic unit cell parameter from $a=8.179 \AA$ for LMNO to $a=8.007 \AA$ for $\lambda$-MNO. This trend is similar to that observed upon delithiation of LMO. The Raman spectrum of $\lambda$-MNO (in red in Fig. 3c) exhibits six bands located at $172,455,495,542,597$ and $635 \mathrm{~cm}^{-1}$. The following assignment scheme can be proposed (Table 1) [38]: The band at $172 \mathrm{~cm}^{-1}$ corresponds to the $F_{2 g}(1)$ mode. The 455 and $495 \mathrm{~cm}^{-1}$ features are assigned to the $E_{g}$ and $F_{2 g}(2)$ modes, respectively. The intense band observed at $542 \mathrm{~cm}^{-1}$ is the $A_{1 \mathrm{~g}}$ phonon involving pure $\mathrm{Ni}^{4+}-\mathrm{O}$ vibrations while the two other $\mathrm{A}_{1 \mathrm{~g}}$ components at 597 and $635 \mathrm{~cm}^{-1}$ correspond to the pure $\mathrm{Mn}^{4+}-\mathrm{O}$ stretching mode (observed at a close frequency of $589 \mathrm{~cm}^{-1}$ in $\lambda$ $\mathrm{MO}$ ) and mixed ( $\mathrm{Mn} / \mathrm{Ni})$ vibrations, respectively [38]. 

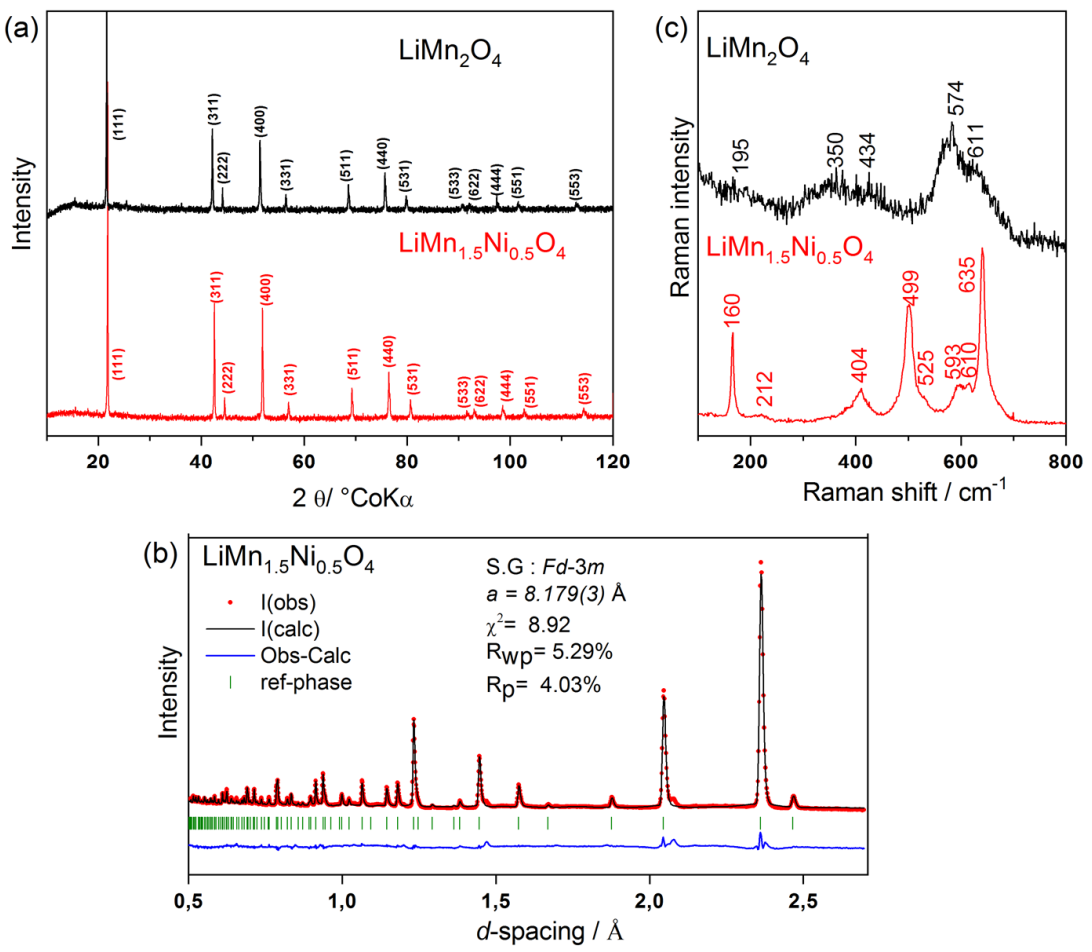

Figure 2. (a) X-ray diffraction patterns of LMO and LMNO as-prepared powders; (b) Rietveld refinement of Time-of-Flight powder neutron diffraction data of LMNO. Experimental data : red circles (GEM, bank detector at $91.30^{\circ}$ ); calculated pattern : black solid line; difference curve shown below the diffraction pattern in blue; vertical bars in green represent the position of Bragg reflections; (c) Raman spectra of LMO and LMNO as-prepared powders.
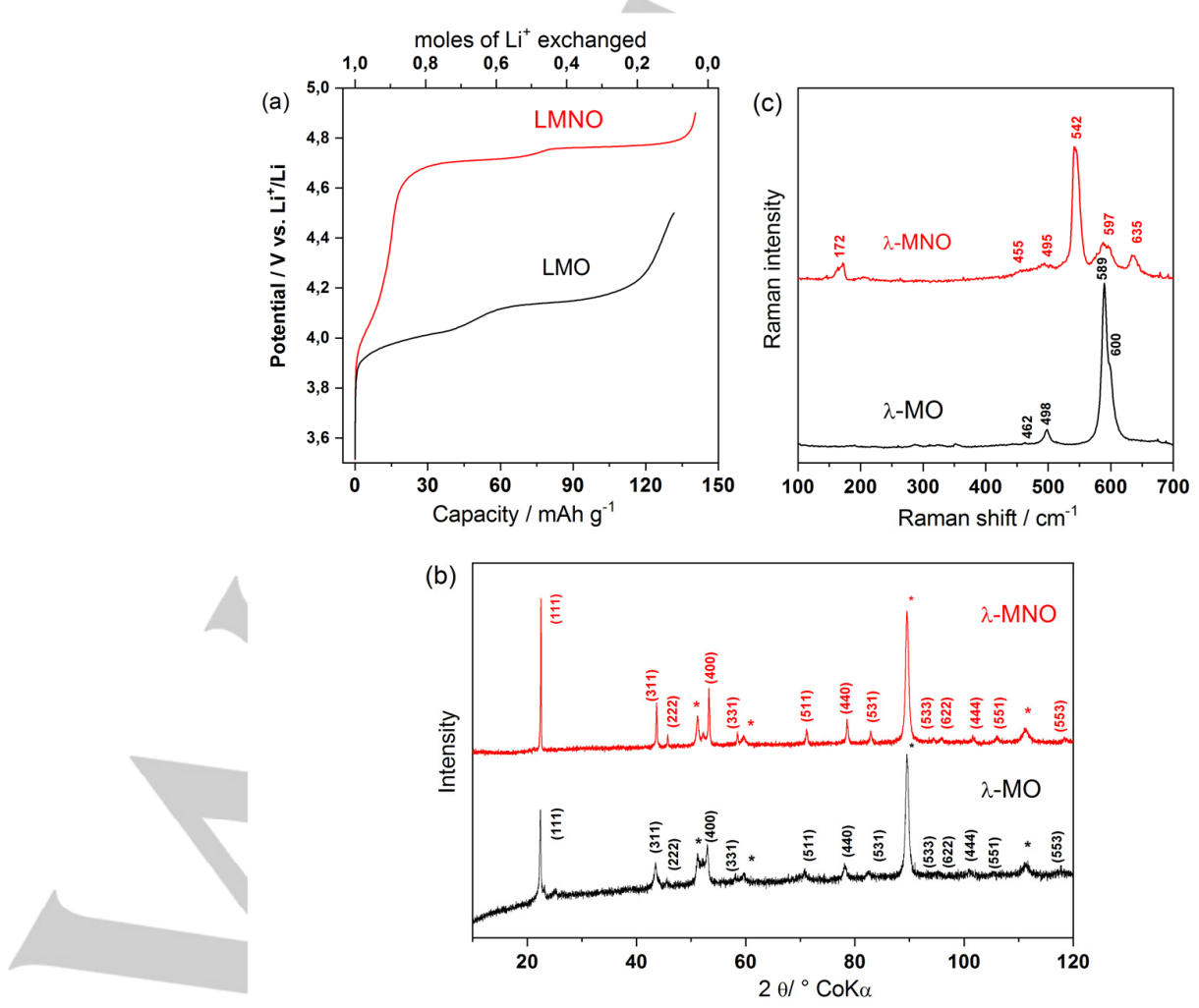

Figure 3. (a) First galvanostatic charge (C/10 rate) in $1 \mathrm{M} \mathrm{LiPF}_{6} / \mathrm{EC}$ : DMC (1:1 vol. \%) electrolyte of LMO and LMNO electrodes. (b) X-ray diffraction patterns of $\lambda$ $\mathrm{MO}$ and $\lambda$-MNO electrodes. Stars correspond to the peaks of stainless steel sample holder; (c) Raman spectra of $\lambda$-MO and $\lambda$-MNO electrodes. 


\section{Electrochemical study of $\lambda$-MO and $\lambda$-MNO in potassium cells}

The first discharge-charge cycle of the $\lambda$-MO electrode in a potassium cell is shown in Fig. 4 a. Starting from the OCV voltage of $3.93 \mathrm{~V}$ vs. $\mathrm{K}^{+} / \mathrm{K}$, the voltage abruptly falls down to ca. $2.65 \mathrm{~V}$ and then decreases along a gentle slope down to $2 \mathrm{~V}$. The total discharge capacity involved in this reduction process is $\sim 130$ $\mathrm{mAh} \mathrm{g}^{-1}\left(0.83 \mathrm{e}^{-/ m o l e}\right.$ of spinel oxide). The EDX analysis of the discharged electrode gives a $\mathrm{K} / \mathrm{Mn}$ ratio of 0.4 , consistent with the composition $\mathrm{K}_{0.84} \mathrm{Mn}_{2} \mathrm{O}_{4}$, i.e. $\mathrm{K}_{0.42} \mathrm{MnO}_{2}(\mathrm{KMO})$. The consecutive oxidation curve (Fig. 4a) exhibits a high hysteresis and a substantially different voltage profile: a long sloping curve $(\approx 50$ $\mathrm{mAh} \mathrm{g}^{-1}$ of charge capacity) followed by 2 pseudo plateaus at 3.88 and $4.10 \mathrm{~V}$. This suggests that some irreversible structural change has occurred during the first reduction process. A charge capacity of $105 \mathrm{mAh} \mathrm{g}^{-1}$ is recovered, corresponding to the extraction of $\approx 0.34 \mathrm{~K}^{+}$from $\mathrm{KMO}$ to lead to $\mathrm{K}_{\sim 0.08} \mathrm{MnO}_{2}$. The EDX analysis of the charged electrode gives a $\mathrm{K} / \mathrm{Mn}$ ratio of $1 / 12$ $\left(\mathrm{K}_{0.083} \mathrm{MnO}_{2}\right)$, consistent with the faradaic yield. The second discharge (Fig. 4b) exhibits a voltage decrease down to $3.5 \mathrm{~V}$ followed by a long sloping curve. The mid-discharge potential is $2.79 \mathrm{~V}$ and the total capacity reached during this second discharge is $\approx 105 \mathrm{mAh} \mathrm{g}^{-1}$. The subsequent charge is quite symmetric, showing a sloping region and two steps at 3.85 and 4.1 V. A good efficiency of the potassium extraction/insertion reaction is observed from the second cycle. Further dischargecharge cycles show nevertheless a continuous lowering of the operation voltage and significant capacity fading (Fig. 4c). Indeed, the retained capacity is approximately $38 \%$ after 30 cycles: a sharp decrease is observed during the first 15 cycles, from 105 to $50 \mathrm{mAh} \mathrm{g}^{-1}$ (3.7 $\mathrm{mAh} \mathrm{g}^{-1} /$ cycle), with a value of $40 \mathrm{mAh} \mathrm{g}^{-1}$ achieved after 30 cycles (Fig. $4 \mathbf{d}$ ).

The first discharge-charge cycle of the $\lambda$-MNO electrode in a potassium cell is shown in Fig. 5a. The $\mathrm{Li}_{0.02} \mathrm{Mn}_{0.75} \mathrm{Ni}_{0.25} \mathrm{O}_{2}$ chemical composition of $\lambda$-MNO indicates the presence of $\mathrm{Mn}$ and $\mathrm{Ni}$ in their highest +IV oxidation state. Starting from the OCV voltage of $3.87 \mathrm{~V}$ vs. $\mathrm{K}^{+} / \mathrm{K}$, the voltage quickly falls down to $\sim 2.13$ $\mathrm{V}$ then raises rapidly to $2.70 \mathrm{~V}$ to decrease down to $2.00 \mathrm{~V}$ along a gentle slope involving a total capacity of c.a. $150 \mathrm{mAh} \mathrm{g}^{-1}$. The initial potential drop immediately followed by a voltage increase that reaches rapidly a pseudo plateau is probably due to the difficulty to accommodate $\mathrm{K}^{+}$ions at the beginning of the first discharge. Indeed, the insertion of the very first $\mathrm{K}^{+}$ions requires an expansion of the interlayer distance, which is a difficult reaction due to the large size of $\mathrm{K}^{+}$. Then, the subsequent $\mathrm{K}^{+}$insertion is much easier and the working potential raises to $2.70 \mathrm{~V}$. The composition of the discharged electrode, $\mathrm{K}_{0.5} \mathrm{Mn}_{0.75} \mathrm{Ni}_{0.25} \mathrm{O}_{2}$ (KMNO) is consistent with the EDX analysis giving a $\mathrm{K} / \mathrm{Ni}$ ratio of 1.91. Owing to the faradaic yield $\left(0.5 \mathrm{e}^{-/} \mathrm{mol}\right.$ of $\left.\lambda-\mathrm{MNO}\right)$, only $\mathrm{Mn}^{3+}$ and $\mathrm{Ni}^{3+}$ species can be produced during discharge. As previously observed for $\lambda-\mathrm{MO}$, the consecutive oxidation curve (Fig. 5a) exhibits a large hysteresis and a different profile, in line with the occurrence of irreversible structural change during the first reduction. It consists in a long sloping curve $\left(\approx 60 \mathrm{mAh} \mathrm{g}^{-1}\right.$ of charge capacity) followed by a pseudo plateau at $4.40 \mathrm{~V}$ involving an additional capacity of $\approx 30 \mathrm{mAh} \mathrm{g}^{-1}$. The total charge capacity of $93 \mathrm{mAh} \mathrm{g}^{-1}$ corresponds to the extraction of $0.3 \mathrm{~K}^{+}$from KMNO, leading to $\mathrm{K}_{\sim 0.2} \mathrm{Mn}_{0.75} \mathrm{Ni}_{0.25} \mathrm{O}_{2}$. The EDX analysis of the charged electrode gives consistent $\mathrm{K} / \mathrm{Ni}$ and $\mathrm{K} / \mathrm{Mn}$ ratios of 0.9 and 0.26 , respectively. The second discharge curve (Fig. 5b) exhibits a quasi-voltage plateau at $\sim 4.10 \mathrm{~V}$ involving $\approx 30 \mathrm{mAh} \mathrm{g}^{-1}$ of discharge capacity, then a second step at $3.26 \mathrm{~V}$ followed by a sloping decrease down to the $2.00 \mathrm{~V}$ cut-off voltage $(\approx 60 \mathrm{mAh} \mathrm{g}$ ${ }^{1}$ of additional discharge capacity). The reversible capacity value of $90 \mathrm{mAh} \mathrm{g}^{-1}$ displayed by KMNO is comparable to the values of $\sim 100 \mathrm{mAh} \mathrm{g}^{-1}$ usually reported for layered manganese oxides investigated as cathode materials for KIBs [14- 21]. Interestingly, the mid-discharge potential value of $\sim 3.10 \mathrm{~V}$ is $\sim 0.3 \mathrm{~V}$ higher than that observed for $\lambda$-MO. The consecutive charge is nearly symmetric, showing a wide sloping region followed by a quasivoltage plateau at $4.40 \mathrm{~V}$. A good efficiency of the potassium extraction/insertion reaction is observed for this second cycle. It is noteworthy that the electrochemical profile obtained from the second cycle (Fig. 5b) and retained upon further cycles (Fig. 5c) completely differs from that observed during the first discharge (Fig. 5a). This steady electrochemical fingerprint obtained from the second cycle (Fig. 5b) exhibits close resemblance with the typical profile reported for $\mathrm{K}_{x} \mathrm{MnO}_{2}$ structures in $\mathrm{K}$-containing electrolyte, characterized by a smooth variation in the $4 \mathrm{~V}-1.5 \mathrm{~V}$ or $4.2 \mathrm{~V}-1.5 \mathrm{~V}$ voltage ranges [14-21]. Such observations suggest the occurrence of a major structural change during the first discharge ok KMNO and $\mathrm{KMO}$, corresponding to a spinel to layered phase transformation. Furthermore, comparison of the discharge-charge profiles displayed by KMO (Fig. 4b) and KMNO (Fig. 5b) reveals the existence of an additional insertion/extraction step at 4.1/4.4 V for KMNO (Fig. S3). This clearly indicates the participation of $\mathrm{Ni}$ ions in the redox reactions. It is noteworthy such high voltage plateau was not observed in the case of the Ni-substituted $\mathrm{K}_{0.5} \mathrm{Ni}_{0.1} \mathrm{Mn}_{0.9} \mathrm{O}_{2}$ oxide [21], for which $\mathrm{Ni}^{3+} / \mathrm{Ni}^{2+}$ and $\mathrm{Mn}^{4+} / \mathrm{Mn}^{3+}$ redox processes were involved below 4 $\mathrm{V}$. Hence, the occurrence of the $\mathrm{Ni}^{4+} / \mathrm{Ni}^{3+}$ transition at a higher voltage of $4.1 / 4.4 \mathrm{~V}$ can be safely proposed for KMNO. This high voltage step involves a faradaic yield of $\approx 30 \mathrm{mAh} \mathrm{g}^{-1}$, which indicates that $0.1 \mathrm{e}^{-}$would contribute to the $\mathrm{Ni}^{4+} / \mathrm{Ni}^{3+}$ redox reaction while the remaining $0.2 \mathrm{e}^{-}$would be implied in the $\mathrm{Mn}^{4+} / \mathrm{Mn}^{3+}$ transition occurring at lower voltage (from $3.5 \mathrm{~V}$ to $2 \mathrm{~V}$ ).

Cycling tests of KMNO, shown in Fig. 5c-d, reveal a better behavior than that observed for the non-substituted KMO electrode (Fig.4c-d). Indeed, the capacity decreases in a lesser extent during the first 15 cycles $\left(1 \mathrm{mAh} \mathrm{g}^{-1} /\right.$ cycle against $3.7 \mathrm{mAh}$ $\mathrm{g}^{-1} /$ cycle for KMO). The retained capacity is approximately $80 \%$ after 60 cycles, with a practically stable value of $72 \mathrm{mAh} \mathrm{g}^{-1}$ from the $15^{\text {th }}$ cycle (Fig. 5d). Such value overpasses the capacity retention observed for the non-substituted $\mathrm{K}_{0.3} \mathrm{MnO}_{2}$ [14], $\mathrm{K}_{0.45} \mathrm{MnO}_{2}$ [15] and $\mathrm{K}_{0.5} \mathrm{MnO}_{2}$ [16] materials, limited to retention capacities in the range $40-66 \%[14-16,19]$. On the other hand, the present capacity retention compares well with some results reported for $\mathrm{Co}$ and $\mathrm{Ni}$-substituted manganese oxides. For instance, a value of around $80 \%$ after 100 cycles is reached for $\mathrm{Fe}, \mathrm{Ni}$ and Co-substituted oxides such as $\mathrm{K}_{0.7} \mathrm{Fe}_{0.5} \mathrm{Mn}_{0.5} \mathrm{O}_{2}$ [17], $\mathrm{K}_{0.5} \mathrm{Ni}_{0.1} \mathrm{Mn}_{0.9} \mathrm{O}_{2}$ [19] and $\mathrm{K}_{0.54} \mathrm{Co}_{0.5} \mathrm{Mn}_{0.5} \mathrm{O}_{2}$ [21]. It is noteworthy the excellent coulombic efficiency achieved here for KNMO after only a few cycles (Fig $\mathbf{5 d}$ ) while lower values of $92-98 \%$ have been reported for the $\mathrm{Ni}$-doped and $\mathrm{Co}$ - substituted layered potassium manganese oxides [19, 21]. 

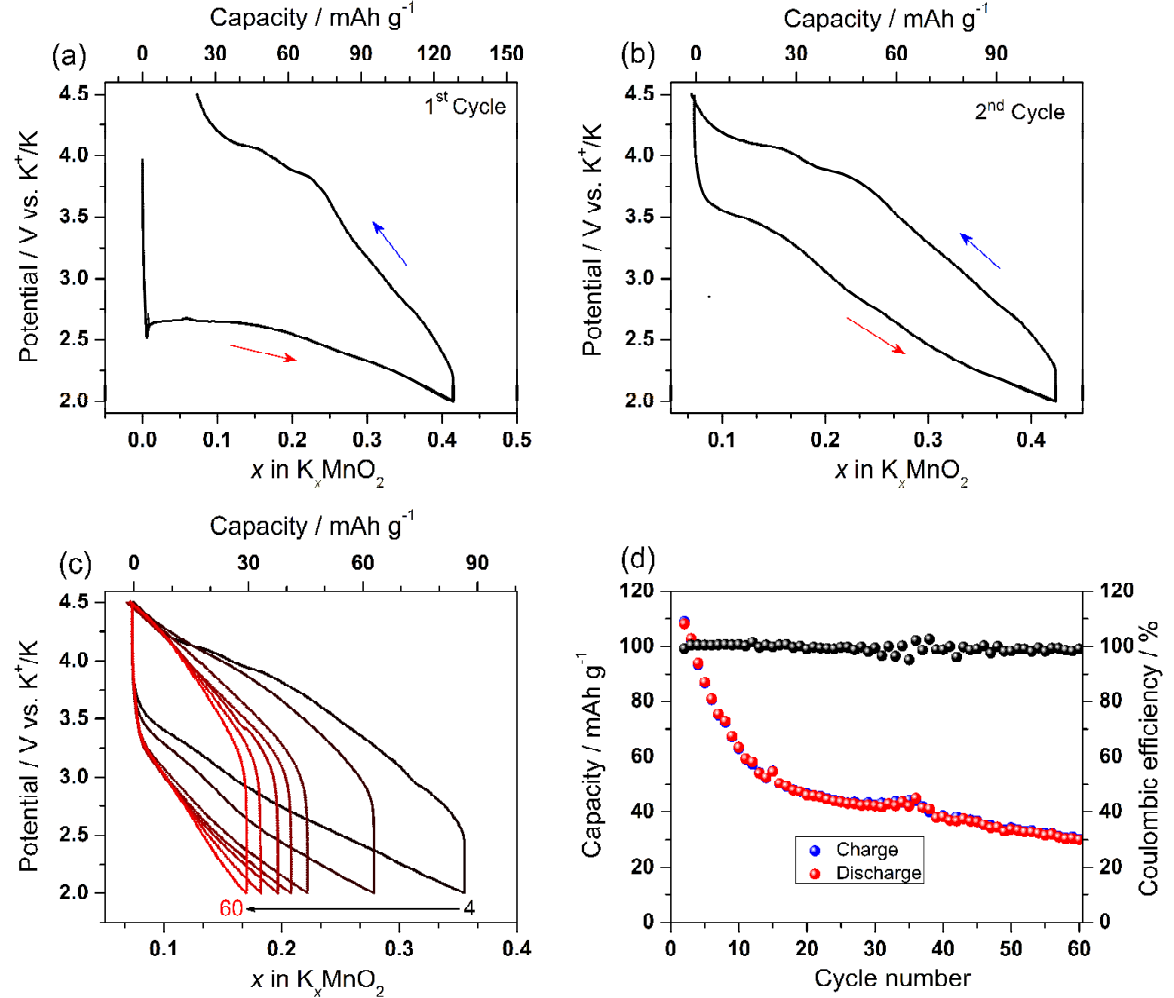

Figure 4. Electrochemical properties in $\mathrm{K}$ cell at $\mathrm{C} / 20$ rate: (a) First discharge-charge cycle of $\lambda$-MO electrode; (b) Second and (c) further cycles of electroformed KMO; (d) Evolution of the charge/discharge capacity and coulombic efficiency vs. number of cycles. Electrolyte $0.5 \mathrm{M} \mathrm{KPF} / \mathrm{EC}$ : PC (1:1 vol. \%), $2 \%$ vol. FEC. Voltage window $4.5 \mathrm{~V}-2 \mathrm{~V}$.
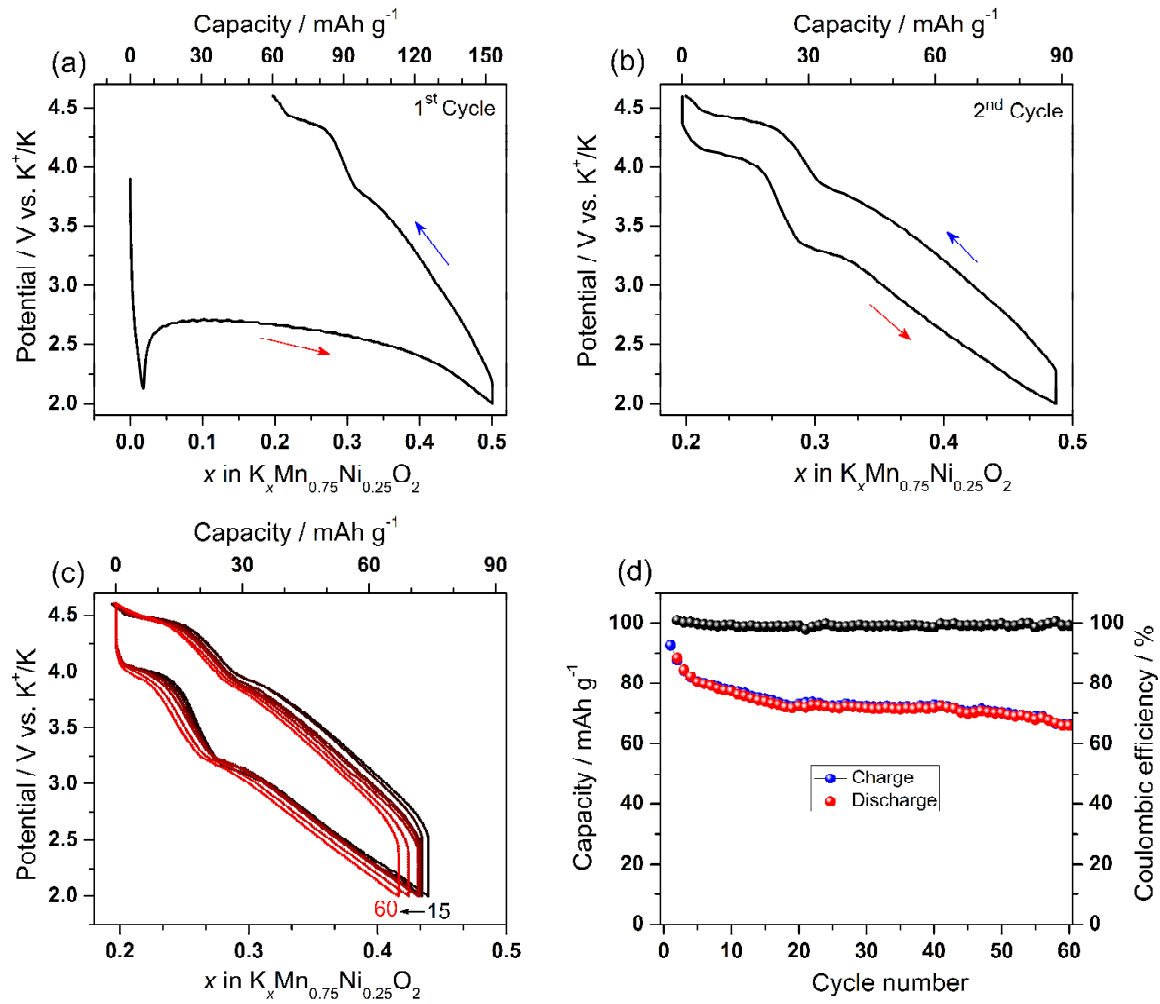

Figure 5. Electrochemical properties in $\mathrm{K}$ cell at $\mathrm{C} / 20$ rate: (a) First discharge-charge cycle of $\lambda$-MNO electrode; (b) Second and (c) further cycles of electroformed KNMO; (d) Evolution of the charge/discharge capacity and coulombic efficiency vs. number of cycles. Electrolyte $0.5 \mathrm{M} \mathrm{KPF}_{6} / \mathrm{EC}$ : PC (1:1 vol. \%), $2 \%$ vol. FEC. Voltage window $4.6 \mathrm{~V}-2 \mathrm{~V}$. 
(A)

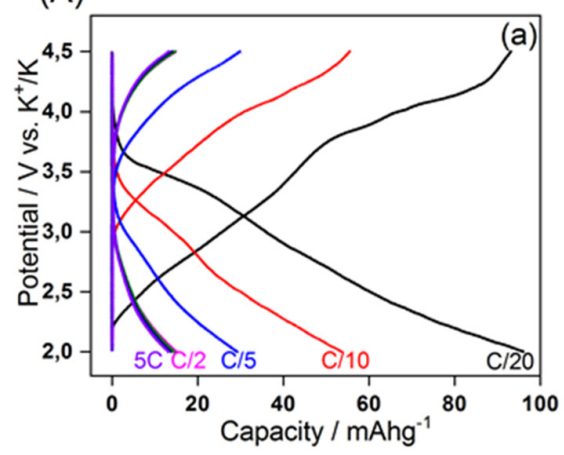

(B)

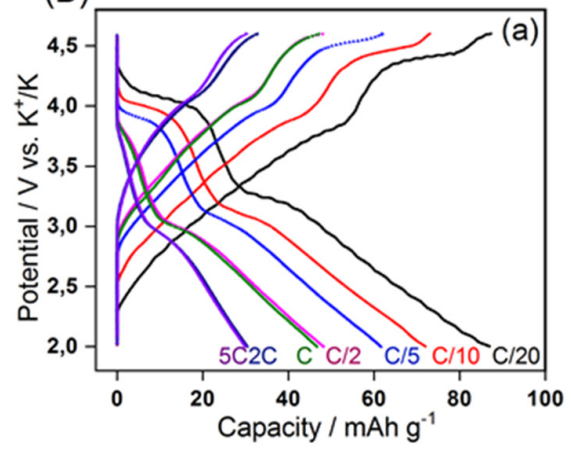

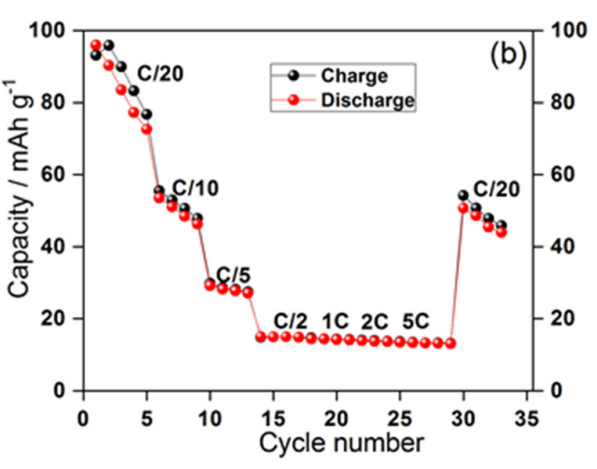

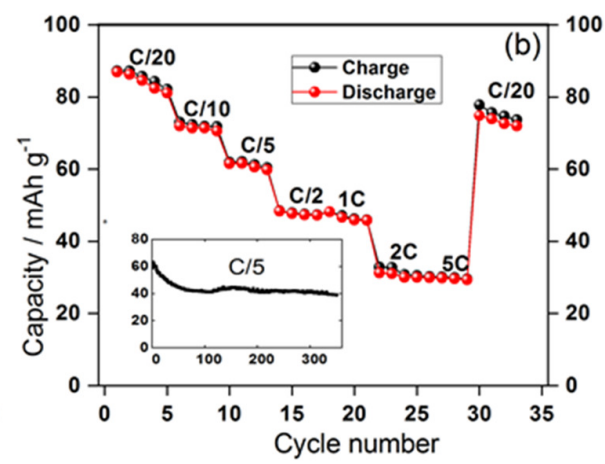

Figure 6. Rate capability behavior in the $\mathrm{C} / 20-5 \mathrm{C}$ range of $(\mathrm{A}) \mathrm{KMO}$; (B) KMNO electrodes. Electrolyte $0.5 \mathrm{M} \mathrm{KPF} / \mathrm{EC}$ : PC (1:1 vol. \%), $2 \%$ vol. FEC

Rate capability tests in the $\mathrm{C} / 20-5 \mathrm{C}$ range confirm the promising performance of KMNO (Fig 6). While a strong influence of the current density is observed for KMO (Fig. 6A), KNMO displays a lesser capacity decrease (Fig. 6B) : from $90 \mathrm{mAh} \mathrm{g}^{-1}$ at C/20 to 72 $\mathrm{mAh} \mathrm{g}^{-1}$ at $\mathrm{C} / 10,60 \mathrm{mAh} \mathrm{g}^{-1}$ at $\mathrm{C} / 5$, still $50 \mathrm{mAh} \mathrm{g}^{-1}$ at $\mathrm{C} / 2$ and $\mathrm{C}$ and $30 \mathrm{mAh} \mathrm{g}^{-1}$ at $2 \mathrm{C}$ and $5 \mathrm{C}$. Close value of $75 \mathrm{mAh} \mathrm{g}^{-1}$ recovered at $\mathrm{C} / 20$ indicates that $\mathrm{K}_{0.5} \mathrm{Mn}_{0.75} \mathrm{Ni}_{0.25} \mathrm{O}_{2}$ can support high C-rate without irreversible structural damages. It is also worth noticing the promising long-term cycling performance: a capacity of $40 \mathrm{mAh} \mathrm{g}^{-1}$ stable over 350 cycles can be reached at C/5 (inset in Fig. 6Bb). These results highlight the superior performance of the $\mathrm{KMNO}$ material, suggesting that the introduction of $\mathrm{Ni}$ in $\mathrm{K}_{x} \mathrm{MnO}_{2}$ plays a significant role in enhancing the diffusion of large potassium ions within the structural framework of the electrode material. A recent paper reporting diffusivity measurements on $\mathrm{Ni}$-free and $\mathrm{Ni}$-doped layered manganese oxides supports this assumption. Indeed, diffusivity values for $\mathrm{K}^{+}$were estimated in the range $10^{-13} / 10^{-11}$ and $10^{-15} / 10^{-11} \mathrm{~cm}^{2} \mathrm{~s}^{-1}$ in $\mathrm{K}_{0.67} \mathrm{Mn}_{0.83} \mathrm{Ni}_{0.17} \mathrm{O} 2$ and $\mathrm{K}_{0.67} \mathrm{MnO}_{2}$ cathode materials, respectively [20].

A study by XRD and Raman spectroscopy has been carried out to characterize the structure of the electroformed KMNO and its evolution during charge-discharge cycles. Fig. 7A presents the Xray diffraction patterns of $\lambda$-MNO electrodes after the first discharge (electroformed KMNO electrode), after the consecutive charge at $4.6 \mathrm{~V}$, discharged after one cycle (cut-off voltage of $2 \mathrm{~V}$ ) and after 50 cycles. All the patterns exhibit reflection peaks that can be indexed within a rhombohedral system ( $R-3 m$ space group) corresponding to a layered structure in which $\mathrm{K}^{+}$ions are sitting in prismatic sites between the transition metal layers of
$\mathrm{MO}_{6}$ octahedra $(\mathrm{M}=\mathrm{Mn}, \mathrm{Ni})$. It is consistent with the structure of several $\mathrm{K}_{\mathrm{x}} \mathrm{MnO}_{2}$ compounds previously described in the literature for $x=0.3[14,15], x=0.45$ [15] and $x=0.5$ [16]. The lattice parameters of the $\mathrm{K}_{0.5} \mathrm{Mn}_{0.75} \mathrm{Ni}_{0.25} \mathrm{O}_{2}$ discharged electrode: $a=b \sim$ $2.892 \AA$ and $c \sim 18.945 \AA$ (hexagonal axes, unit cell volume of $274.4 \AA^{3}$ ) are close to those previously reported for $\mathrm{P} 3-\mathrm{K}_{0.45} \mathrm{MnO}_{2}$ [15], P3- $\mathrm{K}_{0.5} \mathrm{MnO}_{2}$ [16] as well as $\mathrm{P} 3-\mathrm{K}_{0.5} \mathrm{Ni}_{0.1} \mathrm{Mn}_{0.9} \mathrm{O}_{2}$ [19]. The diffraction pattern of the oxidized electrode (Fig. 7Ab), with composition $\mathrm{K}_{0.2} \mathrm{Mn}_{0.75} \mathrm{Ni}_{0.25} \mathrm{O}_{2}$, displays a noticeable shift toward lower $2 \theta$ value of the 003 and 006 reflections indicating an increase in the interlayer $c$ parameter upon $\mathrm{K}^{+}$extraction. Indeed, the unit cell parameters of the electrode after one dischargecharge cycle are: $a=b \sim 2.856 \AA$, and $c \sim 21.367 \AA$ (unit cell volume of $\left.301.9 \AA^{3}\right)$. This significant volume expansion $(\Delta \mathrm{V} / \mathrm{V} \sim$ $10 \%$ ) is ascribed to increasing electrostatic repulsion between the negative slabs on the departure of the large interlayer potassium cations, as previously described for other K-containing layered structures [44]. Then, a reverse trend is observed upon the second discharge (Fig. 7Ac), indicating the reversible character of the expansion-contraction cycles upon successive extractioninsertion of $\mathrm{K}$ ions. The diffraction pattern of the electrode after 50 cycles (Fig. 7Ad) exhibits a quite lower intensity reflecting the occurrence of some disorder after multiple expansion-contraction processes. The most intense 003 line is no more observable in the low $2 \theta$ region but the positions of the $006,101,10-2$, and 10 5 reflections at higher $2 \theta$ angle well match those of the electrode after the first cycle (see Fig.7Ab), showing the layered arrangement is retained even after 50 cycles. 
Raman spectroscopy is particularly useful for analyzing the local structure of manganese dioxides, especially for samples with poor crystallinity for which it is difficult to apply the Rietveld refinement of the XRD data [37]. Several papers on the vibrational spectra of various polymorphs of $\mathrm{MnO}_{x}$ show the Raman spectra features are diagnostic of the $\mathrm{Mn}-\mathrm{O}$ skeleton and structural arrangement of basic $\mathrm{MnO}_{6}$ entities [45- 47]. Fig. 7B presents the Raman spectra of $\lambda$-MNO electrodes after the first discharge (KMNO) and after the second discharge. The Raman spectrum of the KMNO discharged electrode (Fig.7Ba) displays similar features to the layered-type birnessite $\delta-\mathrm{MnO}_{2}[46,47]$. The basic structure of the birnessite group has been inferred to be similar to that of chalcophanite, consisting in $\mathrm{MnO}_{6}$ octahedra layers separated by layers of lower-valent cations $\left(\mathrm{Li}^{+}\right.$or $\left.\mathrm{Na}^{+}\right)$and by layers of water. The most intense Raman bands at 575 and $646 \mathrm{~cm}^{-1}$ in the Raman spectrum of birnessite have been assigned to the $v(\mathrm{Mn}$ O) in-plane stretching vibrations. The $575 \mathrm{~cm}^{-1}$ feature was related to the specific vibrations in regular $\mathrm{Mn}^{\mathrm{IV}} \mathrm{O}_{6}$ octahedra [46]. The Raman spectrum of KMNO displays six Raman bands at 355 , $480,506,572,596$ and $639 \mathrm{~cm}^{-1}$. The two major features at 596 and $639 \mathrm{~cm}^{-1}$ correspond to the in-plane metal-oxygen stretching vibrations. The $596 \mathrm{~cm}^{-1}$ band can be safely assigned to the
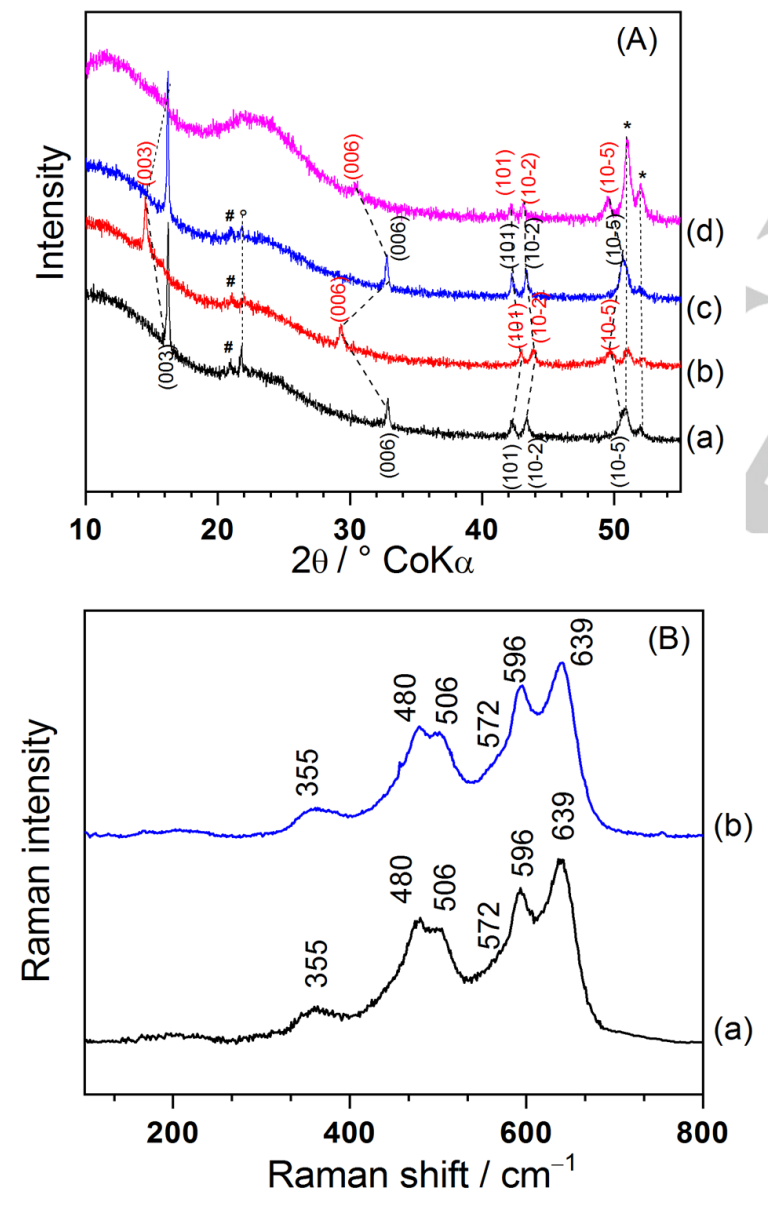

Figure 7. (A) Ex-situ XRD patterns of (a) electroformed KMNO electrode; (b) charged to $4.6 \mathrm{~V}$ (c) discharged after 1 cycle (d) after 50 cycles. *: reflections of stainless steel sample holder; \#: reflections of PTFE, ${ }^{\circ}$ : reflection of LMNO trace. (B) Raman spectra of (a) electroformed KMNO electrode (b) discharged after 1 cycle.
$v\left(\mathrm{Mn}^{\mathrm{IV}}-\mathrm{O}\right)$ vibration while the Raman band at $639 \mathrm{~cm}^{-1}$ can be viewed as the symmetric stretching vibration $v(\mathrm{M}-\mathrm{O})$ in $\mathrm{NiO}_{6}$ and $\mathrm{MnO}_{6}$ octahedra.

The two peaks at 480 and $506 \mathrm{~cm}^{-1}$ are commonly assigned to the out-of-plane $\mathrm{Mn}-\mathrm{O}$ and $\mathrm{Ni}-\mathrm{O}$ stretching vibrations, respectively [47]. Hence, the $506 \mathrm{~cm}^{-1}$ peak corresponds to a pure Ni vibration while $\mathrm{Mn}$ and Ni vibrations cannot be discriminated in the $639 \mathrm{~cm}^{-}$ 1 band. The Raman spectrum recorded after the second discharge (Fig. 7Bb) is perfectly superimposed to that observed for the first reduction product (KMNO), which indicates the reversible character of the successive extraction-insertion of $\mathrm{K}^{+}$ ions at the atomic scale.

\section{Conclusion}

This paper explores for the first time the feasibility of the high voltage spinel LMNO oxide as a precursor for preparing the $\mathrm{Li}$ free $\lambda$-MNO used as cathode material for KIB. The discharge of the electrochemically delithiated $\lambda$-MNO electrode in a $\mathrm{KPF}_{6} / \mathrm{EC}: \mathrm{PC}$ electrolyte is shown to produce irreversibly the $\mathrm{Ni}-$ substituted layered manganese oxide, $\mathrm{K}_{0.5} \mathrm{Mn}_{0.75} \mathrm{Ni}_{0.25} \mathrm{O}_{2}$ (KMNO), with P3 rhombohedral symmetry ( $R-3 m$ space group; $a=b \sim$ $2.892 \AA$; $c \sim 18.945 \AA$ ). KMNO exhibits promising properties as cathode material for KIBs. About $0.3 \mathrm{~K}^{+}$ion can be reversibly exchanged at $\mathrm{C} / 20$, corresponding to a specific capacity of 90 $\mathrm{mAh} \mathrm{g}^{-1}$ in the $4.6-2.0 \mathrm{~V}$ voltage window. The typical dischargecharge fingerprint of KMNO shows a peculiar but highly reversible insertion-extraction step located at $4.1-4.4 \mathrm{~V}$, suggesting the $\mathrm{Ni}^{4+} / \mathrm{Ni}^{3+}$ redox couple is involved in addition to the $\mathrm{Mn}^{4+} / \mathrm{Mn}^{3+}$ reaction occurring in the $3.5-2 \mathrm{~V}$ range. Comparison with $\mathrm{KMO}$ clearly shows an increase in the working potential (3.1 V for $\mathrm{KMNO}$ vs. $2.8 \mathrm{~V}$ for $\mathrm{KMO}$ ) and an improved structural stability upon cycling (70 mAh g ${ }^{-1}$ available after 60 cycles at $\mathrm{C} / 20$ for KMNO against only $40 \mathrm{mAh} \mathrm{g}^{-1}$ for $\mathrm{KMO}$ ). The better rate capability also evidenced for KMNO suggests a faster potassium diffusion within the host structure. The excellent coulombic efficiency of KMNO allows good performance upon extended cycling with still $40 \mathrm{mAh} \mathrm{g}^{-1}$ after 350 cycles at $\mathrm{C} / 5$, which is among the highest number of cycles never reported for a cathode material used in KIBs. The present comparative study shows that the presence of $\mathrm{Ni}$ as partial substituent for $\mathrm{Mn}$ seems to be effective in lowering the Jahn-Teller effect and reducing the structural deterioration, resulting in more migration pathways for $\mathrm{K}$ ions, thus enhancing the rate capability and cycling performance. Further work is required to fully elucidate the electrochemical mechanism reaction and to improve the KMNO cycling performance, in particular by using a nanosizing approach and by lowering the cutoff voltage to $1.5 \mathrm{~V}$.

\section{Experimental Section}

$\mathrm{LiMn}_{2-\mathrm{xNi}} \mathrm{NiO}_{4}$ powders $(\mathrm{x}=0$ and $\mathrm{x}=0.5$ ) were synthesized using the coprecipitation route described in [48]. For $x=0.5$, stoichiometric amounts of manganese, lithium and nickel acetates (99\% Aldrich) and oxalic acid powder (1:1 molar ratio of oxalic acid to metal ions) were dissolved in distilled water and stirred for 30 minutes. After stirring, the green (for $x=$ 
0.5 ) or light pink (for $x=0$ ) precipitate is dried at $110^{\circ} \mathrm{C}$ overnight, then at $490{ }^{\circ} \mathrm{C}$ for 6 hours. The preheated powder was pressed into pellets and annealed at $900^{\circ} \mathrm{C}$ for 96 hours in air This synthetic route provides good crystallinity of the $F d-3 m$ phase with disordered $\mathrm{Ni}$ and $\mathrm{Mn}$ for $\mathrm{x}=0.5$. The powders were characterized by scanning electron microscopy (SEM), Zeiss, Merlin-type microscope. Energy dispersive X-ray (EDX) analysis was applied to determine the elements of powders together with SEM with an accelerating voltage of 10-15 kV; atomic Ni/Mn ratio of 1:2.9 was found for the LMNO powder. This slight deviation from the expected 1:3 stoichiometry is due to oxygen loss at annealing temperatures higher than $\sim 700^{\circ} \mathrm{C}$ and the presence of Ni-rich impurities. Thermal gravimetric analysis (TGA) was used to quantify the oxygen stoichiometry. Estimated values of 3.97 and 3.99 were found for LMO and LMNO powders, respectively.

Crystal structures were characterized using powder neutron diffraction (PND), X-ray diffraction (XRD) as well as Raman spectroscopy. The timeof-flight powder neutron diffraction data (PND) on LMNO were collected at ambient temperature for 2 hours, using the GEM diffractometer at the ISIS neutron spallation source, STFC Rutherford Appleton Laboratory, UK [49]. XRD experiments were performed using a Panalytical XPert pro apparatus equipped with a X'Celerator detector and Co Ka radiation ( $\left.\lambda_{K \alpha}=1.789 \AA\right)$. The as-collected XRD and PND patterns have been analyzed using Rietveld refinement method with the GSAS ExpGUI package [50, 51]. For XRD and Raman characterizations of electrodes, the cells are opened in the glove box, the positive electrode is removed, washed 3 times with DMC and placed in specifically designated airtight sample holders to avoid any parasitic reaction with ambient atmosphere. The polymer nature of the XRD sample holder leads to a high background with diffuse broad peak centered at $\sim 23^{\circ}$.

Raman spectra were recorded with a LaBRAM HR 800 (Jobin-YvonHoriba) Raman micro-spectrometer including Edge filters and equipped for signal detection with a back illuminated charge coupled device detector (Spex CCD) cooled by Peltier effect to $200 \mathrm{~K}$. A He:Ne laser $(632.8 \mathrm{~nm}$ ) was used as the excitation source. The spectra were measured in backscattering geometry. The resolution was about $0.5 \mathrm{~cm}^{-1}$. A $100 \times$ objective was used to focus the laser light on sample surface to a spot size of $1 \mu \mathrm{m}^{2}$. To avoid local heating of the sample, the power of the laser beam was adjusted to $0.2-0.5 \mathrm{~mW}$ with neutral filters of various optical densities. To check the homogeneity, Raman spectra were recorded on 10 different spots of each sample.

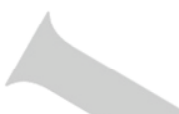

The positive electrode is prepared by mixing $80 \mathrm{wt} \%$ of active material with $15 \mathrm{wt} \%$ of acetylene black and $5 \mathrm{wt} \%$ of PTFE as binder. About 6 $\mathrm{mg}$ of this mix is pressed $\left(4\right.$ tons $\left./ \mathrm{cm}^{2}\right)$ and placed on a stainless steel current collector. CR2032 coin-cells are assembled in argon-filled glovebox where water and oxygen concentrations are kept less than $1 \mathrm{ppm}$. $\mathrm{Li}$ coin-cells are filled with $1 \mathrm{M} \mathrm{LiPF} / \mathrm{EC}: \mathrm{DMC}(1: 1 \mathrm{vol} . \%)$ electrolyte and contain lithium metal as negative electrode. $\mathrm{K}$ coin-cells are filled with 0.5 $\mathrm{M} \mathrm{KPF}_{6} / \mathrm{EC}: \mathrm{PC}$ (1:1 vol.\%) electrolyte, $2 \%$ vol. FEC and contain potassium metal as negative electrode. In both cells, Whatman glass fiber disks soaked by the electrolyte separate the two electrodes.

LMO and LMNO positive electrodes are initially charged in a Li coin-cell in order to fully extract lithium ions. This oxidation step is carried out at a rate of $\mathrm{C} / 10$ (The $\mathrm{C} / \mathrm{n}$ rate is defined as the current to discharge the nominal capacity in $n$ hours) by applying a cut-off voltage of 4.5 and $4.9 \mathrm{~V} \mathrm{vs.} \mathrm{Li}^{+} / \mathrm{Li}$, respectively. Then, after an equilibrium time of 3 hours, the resulting positive electrodes are removed from the Li coin cell, washed 3 times with DMC, structurally characterized and introduced in $\mathrm{K}$ coin-cells to explore the potassium insertion-extraction properties. Electrochemical experiments are carried out at $20^{\circ} \mathrm{C}$ using a VMP3 Biologic apparatus.

\section{Acknowledgements}

The authors acknowledge the French ANR project "CASSIOPES" $N^{\circ}$ 17-CE09-0016-03 for their financial support. Experiments on GEM at the ISIS Pulsed Neutron and Muon Source were supported by a beam time allocation from the Science and Technology Facilities Council using the GEM XPRESS Service (XB1890380).

Keywords: potassium insertion - Ni-substituted spinel manganate $\cdot$ layered manganese oxide $\cdot$ cathode material $\cdot \mathrm{K}$-ion battery

\section{References}

[1] K. Kubota, S. Komaba, J. Electrochem. Soc. 2015, 162, A2538-A2550.

[2] N. Yabuuchi, K. Kubota, M. Dahbi, S. Komaba, Chem. Rev. 2014, 114, 11636-11682.

[3] D. Aurbach, Z. Lu, A. Schechter, Y. Gofer, H. Gizbar, R. Turgeman, Y. Cohen, M. Moshkovich, E. Levi, Nature 2000, 407, 724-727.

[4] M. C. Lin, M. Gong, B. Lu, Y. Wu, D. Y. Wang, M. Guan, M. Angell, C. Chen, J. Yang, B. J. Hwang, H. Dai, Nature 2015, 520, 324-328.

[5] D. Kundu, E. Talaie, V. Duffort, L. F. Nazar, Angew. Chem. Int. Ed. Engl. 2015, 54, 3431-3448.

[6] S. Komaba, T. Hasegawa, M. Dahbi, K. Kubota, Electrochem. Commun. 2015, 60, 172-175.

[7] C. Vaalma, D. Buchholz, S. Passerini, Curr. Opin. Electrochem. 2018, 9 , 41-48.

[8] M. Okoshi, Y. Yamada, S. Komaba, A. Yamada, H. Nakai, J. Electrochem. Soc. 2017, 164 A54-A60.

[9] T. A. Pham, K. E. Kweon, A. Samanta, V. Lordi, J. E. Pask, J. Phys. Chem. C 2017, $12121913-21920$.

[10] K. Chihara, A. Katogi, K. Kubota, S. Komaba, Chem. Commun. 2017, 53, 5208-5211.

[11] J. Han, G. N. Li, F. Liu, M. Wang, Y. Zhang, L. Hu, C. Dai, M. Xu, Chem. Commun. 2017, 53, 1805-1808.

[12] A. Eftekhari, J. Power Sources 2004, 126, 221-228.

[13] X. Jiang, T. Zhang, L. Yang, G. Li, J. Y. Lee, ChemElectroChem 2017, 4, 2237-2242.

[14] C. Vaalma, G. A. Giffin, D. Buchholz, S. Passerini, J. Electrochem. Soc. 2016, 163, A1295-A1299.

[15] C. L. Liu, S. H. Luo, H. B. Huang, Y. C. Zhai, Z. W. Wang, Chem. Engineer. J. 2019, 356, 53-59.

[16] H. Kim, D. H. Seo, J. C. Kim, S. H. Bo, L. Liu, T. Shi, G. Ceder, Adv. Mater. 2017, 29, 1702480.

[17] X. Wang, X. Xu, C. Niu, J. Meng, M. Huang, X. Liu, Z. Liu, L. Mai, Nano Lett. 2017, 17, 544-550.

[18] C. L. Liu, S. H. Luo, H. B. Huang, Y. C. Zhai, Z. W. Wang, , ChemElectroChem. 2019, 6, 2308-2315.

[19] M. Y. Cho, J. Y. Jo, J. U. Choi, S. T. Myung, ACS Applied Mater. Interfaces 2019, 11, 27770-27779.

[20] P. Bai, K. Jiang, X. Zhang, J. Xu, S. Guo, H. Zhou, ACS Appl. Mater. Interfaces 2020, doi.org/10.1021/acsami.9b22237.

[21] J. U. Choi, J. Kim, J-Y. Hwang, J. H. Jo, Y-K Sun, S. T. Myung, Nano Energy 2019, 61, 284-294. 
WILEY-VCH

[22] H. Kim, J. C. Kim, S. H. Bo, T. Shi, D. H. Kwon, G. Ceder, Adv. Energy Mater. 2017, 7, 1700098.

[23] H. Hironaka, K. Kubota, S. Komaba, Chem. Commun. 2017, 53, 36933696.

[24] L. Deng, X. Niu, G. Ma, Z. Yang, L. Zeng, Y. Zhu, L. Guo, Adv. Funct. Mater. 2018, 28, 1800670.

[25] H. Zhang, K. Xi, K.Jiang, X. Zhang, Z. Liu, S. Guo, H. Zhou, Chem. Commun. 2019, 55, 7910-7913.

[26] J. C. Hunter, J. Solid State Chem. 1981, 39, 142-147.

[27] J. M. Tarascon, D. G. Guyomard, B. Wilkens, W. R. Mc Kinnon, P. Barboux, Solid State Ion. 1992, 57, 113-120.

[28] N. Yabuuchi, M. Yano, S. Kuze, S. Komaba, Electrochim. Acta 2012, 82, 296-301.

[29] T. Ohzuku, S. Takeda, M. Iwanaga, J. Power Sources 1999, 81-82, 90 94.

[30] K. Amine, H. Tukamoto, H. Yasuda, Y. Fujita, J. Power Sources 1997, 68, 604-608.

[31] Q. Zhong, A. Bonakdarpour, M. Zhang, Y. Gao, J. Dahn, J. Electrochem. Soc. 1997, 144, 205-213.

[32] J. H. Kim, N. P. W. Pieczonka, L. Yang, ChemPhysChem 2014, 15 , 1940-1954.

[33] T. Ohzuku, M. Kitagawa, T. Hirai, J. Electrochem. Soc. 1990, 137, 769775 .

[34] N. Hagh, G. G. Amatucci, J. Power Sources 1990, 195, 5005-5012.

[35] L. Wang, H. Li, X. Huang, E. Baudrin, Solid State Ion. 2011, 193, 32-38.

[36] J. Cabana, M. Casas-Cabanas, F.O. Omenya, N.A. Chernova, D. Zeng, M.S. Whittingham, C.P. Grey, Chem. Mater. 2012, 24, 2952-2964.
[37] R. Baddour-Hadjean, J. P. Pereira-Ramos, Chem. Rev. 2010, 110, 12781319.

[38] Y. Dridi Zrelli. Thèse Université Paris-Est, 2012. Français. NNT: 2012 PEST1126.

[39] B. Ammundsen, G. R. Burns, M. S. Islam, H. Kanoh, J. Roziere, J. Phys. Chem. B 1999, 103, 5175-5180.

[40] C. Julien, F. Gendron, A. Amdouni, M. Massot, Mater. Sci. Eng. B 2006 130, 41-48.

[41] X. Zhang, F. Cheng, K. Zhang, Y. Liang, S. Yang, J. Lian, J. Chen, RSC Adv. 2012, 2, 5669-5675.

[42] C. M. Julien, M. Massot, Mater. Sci. Eng. B 2003, 97, 217-230.

[43] Q. Shi, Y. Takahashi, J. Akimoto, I. C. Stefan, D. A. Scherson, Electrochem. Solid State Lett. 2005, 8, A521-A524.

[44] R. Baddour-Hadjean, L. T. N. Huynh, D. Batyrbekuly, S.Bach, J. P. Pereira-Ramos, ChemSusChem 2019, 12, 5192-5198.

[45] C. M. Julien, M. Massot, C. Poinsignon, Spectrochim. Acta Part A 2004, 60, 689-700.

[46] C. Julien, M. Massot, Phys. Chem. Chem. Phys. 2002, 4, 4226-4235.

[47] C. Julien, M. Massot, R. Baddour-Hadjean, S. Franger, S. Bach, J. P. Pereira-Ramos, Solid State Ion. 2003, 159, 345-356.

[48] D. Liu, J. Han, J. B. Goodenough, J. Power Sources 2010, 195, 2918 2923.

[49] A. C. Hannon, Nucl. Instrum, Methods Phys. Res. Sect. A 2005, 551, 88 107.

[50] A. C. Larson, R. B. Von Dreele, General Structure Analysis System (GSAS), Los Alamos National Laboratory, Technical Report No. LAUR86-748, 2004.

[51] B. H. Toby, J. Appl. Cryst. 2001, 34, 210-221. 
WILEY-VCH

\section{Entry for the Table of Contents}
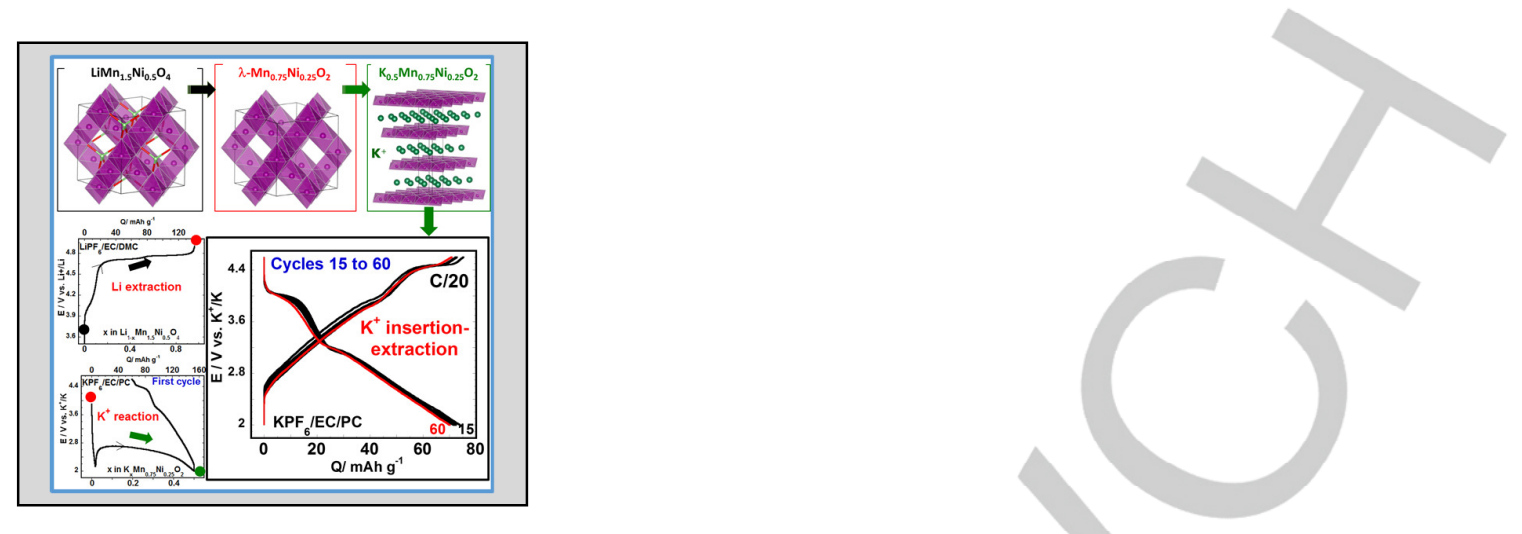

The $\lambda-\mathrm{Mn}_{0.75} \mathrm{Ni}_{0.25} \mathrm{O}_{2}$ spinel structure obtained from electrochemical oxidation of $\mathrm{LiMn}_{1.5} \mathrm{Ni}_{0.5} \mathrm{O}_{4}$ high voltage spinel is investigated as cathode material for $\mathrm{K}$-ion battery. A phase transition toward layered $\mathrm{P} 3-\mathrm{K}_{0.5} \mathrm{Mn}_{0.75} \mathrm{Ni}_{0.25} \mathrm{O}_{2}$ is evidenced during the first discharge in $\mathrm{K}$ cell. Then, $0.3 \mathrm{~K}^{+} / \mathrm{mole}\left(90 \mathrm{mAh} \mathrm{g}^{-1}\right)$ are reversibly exchanged during the subsequent cycle at an average working voltage of $3.10 \mathrm{vs.}$ $\mathrm{K}^{+} / \mathrm{K}$ with good cycling stability from the $15^{\text {th }}$ cycle $\left(70 \mathrm{mAh} \mathrm{g}^{-1}\right.$ after 60 cycles at $\left.\mathrm{C} / 20\right)$. The contribution of the $\mathrm{Ni}$ redox system is revealed as a reason for improved performances compared to unsubstituted $\mathrm{K}_{\mathrm{x}} \mathrm{MnO}_{2}$ cathode. 